\title{
Measles Virus Antibody
}

National Cancer Institute

\section{Source}

National Cancer Institute. Measles Virus Antibody. NCI Thesaurus. Code C118901.

Any antibody that recognizes measles virus. 